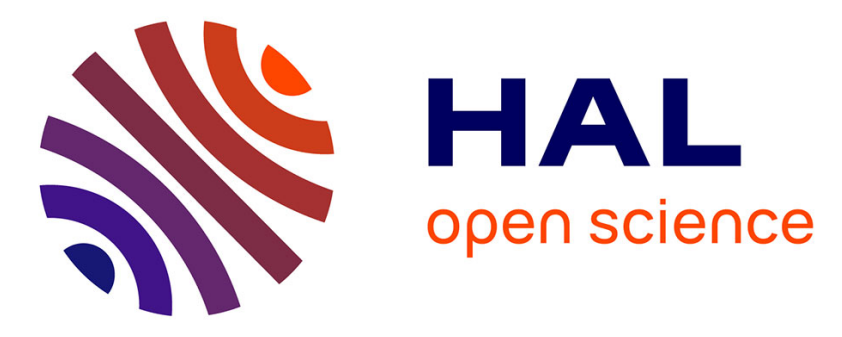

\title{
The Patriarchs and the Union of the Churches
}

Marie-Hélène Blanchet

\section{To cite this version:}

Marie-Hélène Blanchet. The Patriarchs and the Union of the Churches. Christian Gastgeber; Ekaterini Mitsiou; Johannes Preiser-Kapeller; Vratislav Zervan. A Companion to the Patriarchate of Constantinople, 9, Brill, pp.84-102, 2021, Brill's Companions to the Byzantine World, 978-90-04-42443-2. 10.1163/9789004424470_006. hal-03507910

\section{HAL Id: hal-03507910 https://hal.science/hal-03507910}

Submitted on 3 Jan 2022

HAL is a multi-disciplinary open access archive for the deposit and dissemination of scientific research documents, whether they are published or not. The documents may come from teaching and research institutions in France or abroad, or from public or private research centers.
L'archive ouverte pluridisciplinaire HAL, est destinée au dépôt et à la diffusion de documents scientifiques de niveau recherche, publiés ou non, émanant des établissements d'enseignement et de recherche français ou étrangers, des laboratoires publics ou privés. 
The patriarchs and the Union of the Churches

The various attempts at reuniting the Churches punctuated at regular intervals the relationship between the Byzantine Empire and the papacy between 1054 and 1453. This endeavor aimed at the reconciliation between Roman and Byzantine Christians in order to remove the situation of schism between them, and they became the main concern of the whole religious history in that period between the Latin West and the Byzantine East. However, the Patriarchate of Constantinople, and especially its leader, the patriarch, was just one player among many others in these negotiations. Whereas on the Western side the figure of the pope was a key protagonist, both because of his institutional legitimacy as patriarch of Rome and his ability to preach the crusade to rescue the Byzantines against the Turks, on the other side the patriarch of Constantinople could paradoxically claim no specific area of competence in these discussions. The Byzantine representative the pope was speaking with was almost always the emperor, sometimes in agreement with the Orthodox Church, other times in opposition to it, and occasionally even independently of it, when the patriarch was not even being informed about the imperial projects. Among other events, the two councils which led to the Union of the Churches, the second Council of Lyon in 1274 and that of Florence in 1438-1439, evinced the balance of power between the two of them: in both cases, the emperor - Michael VIII, then John VIII Palaeologus - negotiated directly with the pope, while the patriarch - Joseph I, then Joseph II - played a merely advisory part.

This situation stemmed from the distribution of power between Church and State in Byzantium: since Constantine I, the emperor had a legitimate claim to the convening and the presiding over the council, even if he had no say in the definition of the dogma, which was an exclusive prerogative of the Church. This limit to imperial intervention was regularly reminded by the patriarchs to the emperors, but most of the time to no effect: by more or less roundabout means, the emperors went so far as to interfere in the doctrine in order to achieve the Union they were involved in. Consequently, the patriarchs had to bow to imperial will, even if it was driven as much by geopolitical considerations as by desire for Christian unity.

Does this mean that the patriarchs were willingly or unwillingly won over to Union and endorsed it? Most of those who were involved in it between the 11th and the 15th centuries were very reluctant to come back to the full communion with Rome, as they considered the differences between them and the Latins crippling. The few unionist patriarchs in the Byzantine history, John Bekkos after the Union of Lyon, Metrophanes II and Gregory III after 
that of Florence, were exceptions in this regard. If the other leaders of the Byzantine Church overwhelmingly disapproved Union, how did their hostility express itself? Given their prominent position, which stand did they take on the conflict which concerned the whole Byzantine society as far as Union was at stake? Should we think that some patriarchs actually belonged to the anti-unionist movement? Did they oppose Union and did they implement any strategy to make it fail in covert opposition to the emperor?

Dry as it may be, a systematic research of the patriarchal acts related to the question of the Union of the Churches is a prerequisite for this analysis: the patriarchs involved will thus be identified and the corpus of the patriarchal documents will be formed. From these sources, I will attempt to better understand the stands taken by the successive patriarchs and to set them within the spectrum of Byzantine opinions about Union.

Survey of the patriarchal acts related to the Union of the Churches

In addition to the Councils of Lyon and Florence, which are by far the two periods the most productive of patriarchal documents about Union, we can identify more than a dozen of attempts at Union in which a patriarch officially took part between 1054 - date chosen by convention as the one from which the Churches were aware of having broken their communion - and the fall of Constantinople in 1453. I will confine myself to the official documentation and rely on a key tool, the Regestes des actes du patriarcat du Constantinople ${ }^{1}$. The only mentioned acts in the list below are the presupposed authentic patriarchal acts (retained and lost) specifically related to a project of Union with Rome, while other texts, especially letters from patriarchs to popes on another topic, are not taken into account below. Similarly, projects of Union in which a patriarch was not involved are excluded. The retained patriarchal acts, which form the corpus of the patriarchal documents related to the issue of Union, are highlighted in bold.

- Nicholas III Grammatikos (1084-1111), No. 944, 945, 946, 950, 951 (letter to the pope). In 1088-1089, following a letter from pope Urban II who complained of not being commemorated in the diptychs of Constantinople, a council was convened under the presidency of emperor Alexius I Comnenus. It was decided that the commemoration of the pope could be restored when he would sent his letter of accession including his profession of

\footnotetext{
${ }^{1}$ Regestes II-III, Regestes IV, Regestes V, Regestes VI, Regestes VII.
} 
faith. The patriarch wrote to the pope to that end and expressed his desire that Union would be achieved.

- Michael III Anchialos (1170-1178), No. 1125 (letter to the emperor), 1125a (letter to the pope). In 1173, the patriarch replied to a letter of pope Alexander III, who encouraged him to work for Union. In his letter to the pope, Michael III said he relied on the emperor, but in his letter to the emperor, he was very critical vis-à-vis the Latins.

- George II Xiphilinus (1191-1198), No 1183 (letter to the pope, composed by Demetrius Tornikes). In 1193, the patriarch replied to pope Celestine III on the question of primacy and expressed his desire that Union would be achieved.

- John X Kamateros (1198-1206), No. 1194 (letter to the pope). In 1199, the patriarch replied to pope Innocent III on the question of primacy and about the project of Union.

- Theodore II Eirenikos (1214-1216), No. 1219 (encyclical letter to the faithful). In 1214/1215, the patriarch recommended that all Orthodox Christians should refuse any communion with the Latins and should not submit to the pope.

- Germanus II (1223-1240), No. 1256 (letter to the pope), 1257 $^{2}$ (letter to the cardinals), 1267, 1268 (response of the patriarch and his synod about the Holy Spirit, composed by Nicephorus Blemmydes), 1269, 1270, 1271, 1272, 1273 (dogmatic definition of the Holy Spirit), 1274, 1275 (response to the pope), 1276, 1277 (letter to the Latin patriarch of Constantinople). In 1232, the patriarch took the initiative for a correspondence with pope Gregory IX and the cardinals for the sake of the Union of the Churches. Discussions were held at Nicaea, then at Nymphaeum in 1234, but they failed. In 1234, the patriarch reaffirmed the Orthodox doctrine, namely the procession of the Holy Spirit from the Father alone.

- Manuel II (1243-1254), No. 1311, 1313, 1319 (letter to the pope). In the summer of 1253 (or 1250), the patriarch wrote to pope Innocent IV within the context of sending a Byzantine embassy responsible for arranging Union. He expressed his desire that Union would be achieved and mentioned the preparation of a council.

- Arsene Autoreianos (1254-1260, 1261-1264), No. 1332 ${ }^{3}$ (letter to the pope). In 1256, the patriarch wrote to pope Alexander IV within the context of sending a Byzantine embassy responsible for arranging Union. He expressed his desire that Union would be achieved and mentioned the preparation of a council.

\footnotetext{
${ }^{2}$ There is now a critical edition of this letter: see Germanus II, Letter to the cardinals, ed. Arampatzes, pp. $363-$ 378.

${ }^{3}$ There is a new edition of this letter: see Arsene Autoreianos, Letter to the pope, ed. Pieralli, pp. 171-189.
} 
- Joseph I (1266-1275, 1282-1283), No. 1384, 1385, 1399, 1400 $\mathbf{1 4}^{4}$ (Response to the emperor, composed by Job Iasites), 1401 (oath), 1404 (profession of faith), 1408, 1409 (letter licensing the bishops to approve the Union to be signed), 1410, 1413. In 1273, as he was consulted by emperor Michael VIII Palaeologus about his project of Union, patriarch Joseph I expressed great reluctance to such an agreement; he withdrew from his office in early 1274 and announced his resignation if the Union was to be concluded.

- John XI Bekkos (1275-1282), No. 1425, 1428, 1429, 1430, 1431 ${ }^{5}$ (synodal Tomos), 1432 (letter to the pope), $\mathbf{1 4 3 3}^{6}$ (letter to the pope), 1434, 1435 (encyclical letter excommunicating the schismatics), 1436 (joint letter with the Eastern patriarchs to the pope), 1444, 1449, 1450. John XI Bekkos became patriarch in early 1275, after the signing of the Union of Lyon. He did everything during his patriarchate in order to enforce the Union and advocated it in all his writings, especially in 1277 in his letters to pope John XXI.

- Joseph I (1282-1283, 2nd patriarchate), No. 1453, 1454, 1455, 1456, 1457, 1458. The patriarch deposed his predecessor John XI Bekkos and took disciplinary action against those who had been in favour of the Union.

- Gregory II of Cyprus (1283-1289), No. 1463, 1484 (letter possibly addressed to the emperor), 1485 (encyclical letter against Bekkos and the unionists), 1486 (letter to the grand logothete), 1487, $1488,1489,1490$ (tomos against Bekkos). In 1285, the patriarch convened a synod in the Palace of Blachernae and condemned John Bekkos and his unionist companions, whereas he also redefined the Orthodox doctrine.

- John XIV Kalekas (1334-1347), No. 2170. In 1334/1335, the patriarch may have appointed Barlaam of Calabria as a spokesman for the Byzantines during the synodal discussions with the papal legates sent by pope John XXII.

- Kallistos I (1350-1353, 1355-1363), No. $\mathbf{2 4 3 7}^{7}$ (letter to the emperor), 2443 (letter to the clergy of Cyprus). In 1361, in his letter to the emperor, the patriarch dismissed any prospect of Union and stated his hostile opinion; in 1361/1362, he urged the Cypriot clergy not to accept the Union proposed by the papal legate Peter Thomas, sent by pope Innocent VI.

\footnotetext{
${ }^{4}$ All the acts of Joseph I related to the Union of Lyon were edited or reedited in Dossier grec de l'Union de Lyon, ed. Laurent.

${ }^{5}$ This act and the following one were edited or reedited in Dossier grec de l'Union de Lyon, ed. Laurent, pp. 462-467 et 479-485. For recent editions of the official acts of John Bekkos, see Riebe, Rom in Gemeinschaft, pp. 128-129.

${ }^{6}$ This act was reedited in its Greek and Latin versions in La corrispondenza diplomatica, ed. L. Pieralli, Appendix No. 3, pp. 415-431.

${ }^{7}$ This act was reedited in Das Register des Patriarchats von Konstantinopel. 3, ed. J. Koder, n 260 , p. 538-543.
} 
- Philotheus Kokkinos (1353-1354, 1364-1376), No. 2523, 2524 (letter to the archbishop of Ohrid), 2525, 2526. In 1367, after discussions with the papal legate sent by pope Urban V, Paul of Smyrna, it was decided that a council of Union should be organized in Constantinople in 1369. The patriarch then convened the archbishop of Ohrid.

- Nil (1380-1388), No. 2773 (letter to the pope). In 1384, the patriarch replied to pope Urban VI and expressed his desire for Union while clarifying his terms.

- Antonius IV (1389-1390, 1391-1397), No. 3039 (letter to the kral of Poland), 3040 (letter to metropolitan Cyprian of Kiev). In 1397, the patriarch replied to the king of Poland and to Cyprian of Kiev who called for Union; he expressed his desire for Union once circumstances would permit to organize a council.

- Euthymius II (1410-1416), No. 3294. In 1415/1416, within the context of the preparations for the Council of Constance, the patriarch may have sent an embassy for Union.

- Joseph II (1416-1439), No. 3305, 3306, 3309, 3312 (letter to pope Martin V), 3313, 3314, 3316, 3334, 3337, 3338, 3339, 3341, 3342 (letter to the ambassadors of the Council of Basel, preserved in Latin), 3343, 3344, 3346 (letter to pope Eugene IV, preserved in Latin), 3347 (letter to the ambassadors of the Council of Basel, preserved in Latin), 3348 (letter to the ambassadors of the Council of Basel, preserved in Latin), 3349 (letter to an ambassador of the Council of Basel, Henry Menger, preserved in Latin), 3350 (letter to the ambassadors of the Council of Basel, preserved in Latin), 3351, 3352, 3353, 3354, 3355, 3356, 3357 (letter to the Greek ambassadors, preserved in Latin), 3358, 3359, 3360 (letter to the ambassadors of the Council of Basel, preserved in Latin), 3361, 3362, 3363, 3364, 3365, 3367, 3368, 3369, 3370, 3371 (letter to the Greek metropolitans, preserved in Latin), 3373, 3374, 3375, 3376 , 3377 (official opinion of the patriarch), 3378 (profession of faith). In 1422, the patriarch sent a nine-point reply to the proposals of pope Martin $\mathrm{V}$ about Union, he expressed his desire for Union, clarified on which conditions it could be achieved, and especially mentioned the preparation of a council. From 1425 onwards, the patriarch was a partner in the negotiations for Union, on the one hand with representatives of the Council of Basel, on the other hand with pope Eugene IV. He took part in the Council of Ferrara-Florence in 1438-1439 and advocated the Union by signing a unionist profession of faith, just before his death in Florence, June 10, 1439.

- Metrophanes II (1440-1443), No. 3387 (letter to the clergy of Methoni), 3388 (letter to the clergy of Crete), 3391. In 1440, Metrophanes II announced the implementation of the Union of Florence to the Orthodox clergy in the Latin colonies of Methoni and Crete. 
- Gregory III Mammas (1445-1459), No. 3398 (letter to the prince of Kiev, preserved in Old East Slavic and in Latin translation), 3404 (letter to the emperor of Trebizond). In 1447, the patriarch replied to prince Alexander of Kiev and tried to justify the Union. In 1445/1450, the patriarch replied to John IV of Trebizond and tried to justify the Union.

This long list has not much worth in itself, but it aims at providing references to the summaries of the acts and the related bibliography in the Regestes. It sheds light on two aspects of the patriarchs' position about Union: their role in the religious policy of the Byzantine Empire, especially from the 13th to the 15th century, and their official thinking about the issues raised by Union with Rome, especially in doctrinal matters.

The role of the patriarchs in the negotiations for Union

Union was no minor or occasional topic in Byzantium: on the contrary, it was an ongoing question on the agenda, and few were the patriarchs who could escape it. The recurrence of the projects of Union was due to the quasi-constant diplomatic contacts between Rome and Constantinople, but also to the strong presence of the Latins in the East, especially Dominicans and Franciscans, who had settled permanently from the 13th century onwards and were eager to proselytize. A few key moments emerge from this list and let us draw a broad timeline. The need for reuniting the separated Churches was perceived for the first time at the end of the 11th century, but it remained of no effect until the second half of the 12th century. Then, on the contrary, there was already a clear concern for Union. The capture of Constantinople by the Crusaders in 1204 and the founding of the Latin Empire marked a break with the previous period, which was increased by the requirement for submission of the Orthodox clergy to Rome as imposed by pope Innocent III. Several discussions and diplomatic steps then took place between the 1230s and 1270s and led to the Union of Lyon in 1274, which aroused violent reactions in Byzantium. After the rejection of the Union of Lyon between 1283 and 1285 and the disciplinary action taken against the unionists, especially the former patriarch John XI Bekkos, the prospect of Union faded away for decades. It resurfaced in 1334/1335 to almost never disappear afterwards: the second half of the 14th century was punctuated with diplomatic contacts for Union, and this phenomenon intensified even more in the early 15th century. From the 1420s until the Union of Florence in 1439, the patriarch was quite absorbed in the negotiations and preparations for the future council. Lastly, from 1439 to 1453 , the patriarchs in office sought to enforce the Union signed in Florence throughout the whole Orthodox world. 
However, the survey of the patriarchal acts does not completely reflect the negotiations conducted in Byzantium for Union. The bulk of the diplomatic activity in this area was in fact assumed by the emperor. Not only were most of the letters sent by the patriarchs to the popes accompanied by imperial letters - when they were not plain copies of the latter -, but the emperor might also negotiate alone with the papacy. In this regard, it should be noted that no patriarchal act is listed between the 1260s and 1270: Michael VIII discussed alone with popes Urban IV, Clement IV, and Gregory X, and did not seek the advice of the Church and its patriarch before 1273, on the eve of the council. Similarly, emperor John V Palaeologus, who was in favour of the reconciliation with Rome at all costs and had personally converted to the Roman Church in 1369, almost never involved any patriarch in his endeavors to achieve Union throughout the time of his reign, from 1354 to 1390. Some acts by Kallistos I show, however, that the patriarch was aware of John V's discrete manoeuvring for Union and disapproved it, without being able to oppose it.

Weakness and even powerlessness of the patriarchs characterize all these negotiations for Union. It was quite exceptional for a patriarch to take the initiative in starting a correspondence with the pope: so did Germanus II in 1232 and then, together with emperor John III Vatatzes, he went on supervising the organization of embassies and discussions with the Latins, until the process finally failed. But in the vast majority of cases, and already in the 1250 s, during the reign of the same emperor, the patriarch, namely Manuel II, could only comply with the policy followed by his sovereign. John III Vatatzes initiated all the talks held with Innocent IV in the obvious aim to obtain the restoration of the Byzantine Empire; to that end, he would even offer in return that the Byzantine Church should be submitted to the authority of the pope. Without going so far, the conditions negotiated by Michael VIII Palaeologus for the Union of Lyon also implied a loss of autonomy for the Byzantine Church through the reintroduction of the right of appeal to Rome. The emperors handled Union as an instrument of foreign policy, sometimes successfully, and were often ready to make major concessions on the ecclesiastical level in order to gain the alliance of the papacy. Here appears the ambiguous status of the emperor, who could not only act as the defender of Orthodoxy, and as such decide to make Union, but could also invoke the principle of economy, and force the Church to accommodate the interests of the Empire. By virtue of his capacity as an epistemonarch, he was entitled to intervene in ecclesiastical affairs and direct them as he deemed it proper $^{8}$.

\footnotetext{
${ }^{8}$ See especially Geanakoplos, D.J., "Church and State”, 381-403; Dagron, Empereur et prêtre, pp. 260-263, 267, 303-307 et 317 .
} 
How could a patriarch withstand direct pressure from the emperor and indirect authority from the papacy in the context of the preparations for Union? Obviously, his leeway was very limited. He could not take the risk of obstructing the imperial policy, and there is indeed no mention of an open conflict between an emperor and a patriarch on this matter. The strongest opposition was that of Joseph I in 1273, who decided to withdraw to a monastery at the beginning of 1274 and to give up his office if the Union was concluded (see Regestes 1408), which occurred later in 1274. The balance of power was evidently always in favour of the emperor, and for that reason the patriarchs rather sought to warn the sovereign and exert as much influence as possible over his decisions. This was Joseph II's strategy before and during the Council of Ferrara-Florence: he always reaffirmed the priority given by the Church to the preservation of dogma, and opposed the Union to be concluded only "for a semblance of temporary utility." The patriarch could also beg the emperor not to exert undue coercion upon the Church: thus, in Florence in April 1439, while discussions with the Latins had reached an impasse, the patriarch suggested to the emperor to ensure the return of the Byzantine delegation to Constantinople; this request was taken into account by John VIII who used it as a threat to put pressure upon the pope, whereas he certainly did not intend to carry out the repatriation project $^{10}$. As it seems, the patriarch had no decision-making role as regards Union, and the worse the military situation of the Empire got, the more the emperors considered as their only chance of salvation reliance on Latin military support, which was conditioned by Union.

The reluctance of the Church

Even if they were forced to be docile, the patriarchs had their own views on Union and on the possible ways of achieving it. Together with the theologians around them, they had a thorough reflection on the conditions of an acceptable Union, and also developed an argumentation which aimed at condemning the doctrinal errors of the Latins.

One could say with a hint of provocation that all Byzantine patriarchs were unionists, in that they all wished, as they expressed it in their correspondence with the popes, the return to the unity of the Church. This form of unionism was based on an evangelical commandment: in his letters, Apostle Paul always urged the communities he had founded to preserve their unity, whereas he warned them against the spirit of discord and internecine conflicts. Local

\footnotetext{
${ }^{9}$ See Joseph II, Letter to pope Martin V, ed. Laurent, p. 46, line 228, and p. 56.

${ }^{10}$ See Silvester Syropoulos, Memoirs, ed. Laurent, pp. 406-409.
} 
Churches were viewed all together as a single universal Church, which could be assimilated to the seamless robe of Christ (Jn 19, 23), according to one of the many symbolic images of the ecclesiastical institution. It follows that the schism - a split par excellence - was in the same time a sin, a clear violation of God's will, and a suffering, a painful separation, both in the eyes of the Byzantines and the Latins. Consequently, they all shared the same desire for unity, it was even the ground for all discussions between the two parts of the Church. None of them could deny or even relativize the absolute good represented by Union, at the same time reconciliation of all Christians and reconstitution of the original Church. This rhetoric of ideal unity could be found in the writings of the patriarchs, as well as in the assimilation of Union to peace, the supreme value of Christianity ${ }^{11}$.

This fervor, however, was tempered with serious reservations, those justifying that the situation of schism lingered. Several theological issues were the subject of a controversy that dated back to the late first millennium, especially to Photios. Among many other grievances against the Latins, four main ones appeared in the patriarchal acts related to Union: the use of unleavened bread for the Eucharist, the papacy's claim to primacy, the existence of purgatory, and the double procession of the Spirit from the Father and from the Son, or Filioque. As T. Kolbaba clearly showed it $^{12}$, all these criticisms were not uniformly made by the Byzantines to the Latins from the late 11th to the late 15th century. If the question of the Filioque constantly recurred and was considered by the patriarchs and the theologians the most unacceptable doctrinal error of the Latins, the other divisive issues appeared with a specific chronology. Between the 9th and the 13th century, the use of unleavened bread was seen as a major transgression with severe theological consequences, since it was connected with a Judaizing practice; but the question lost much of its controversial content after the Union of Lyon and was not even discussed at the Council of Florence, so that it appeared only in the writings of patriarchs Germanus II, Joseph I and John XI Bekkos. Purgatory was a Western invention of the late 12th century. Therefore this topic, which was never set out as a fundamental complaint, was mentioned in Greco-Latin polemics from the 13th century onwards, in the writings of John XI Bekkos and in the acts of Joseph II at the Council of Florence. Finally the question of Roman primacy was passionately debated in the 12th century with patriarchs George II Xiphilinus and John X Kamateros; then it remained ongoing from the 13 th to the 15 th century, especially in the context of the conciliary discussions, since

\footnotetext{
${ }^{11}$ On this point, given the frequent similarities between the letters of the patriarchs and the letters of the emperors to the popes, see La corrispondenza diplomatica, ed. L. Pieralli, pp. 61-66.

${ }^{12}$ Kolbaba, "Byzantine perceptions", pp. 117-143.
} 
recognition of the primacy of Rome was the first condition required by the papacy. The Byzantines did not challenge the primacy of honor of Rome and could admit that the pope was a primus inter pares, but they refused that this theoretical primacy should confer him a jurisdictional privilege or a higher authority in matters of dogma. In their diplomatic correspondence, the patriarchs briefly hinted at one point or another, most often the Filioque. However, when required to provide a more elaborate theological argumentation, they could expound their position in detail: in this respect, the most exemplary text is the very long Response by Joseph I.

As early as in the beginning of the 13th century, when genuine negotiations for Union began, the Byzantine patriarchs claimed that all these conflicting issues should be examined in the context of a council with the Latins; on the other side, the papacy was not opposed to it. In fact, each of both camps had its own understanding of the nature and authority of the council. The Byzantines wanted to organize the future council on the pattern of the first ones in the early Christian centuries, and they considered that this instance, which brought together the bishops of the whole Church, should be a place for clarification of dogma and rebuttal of heresy, not for a contradictory discussion in which a camp would seek to convince the other. Moreover, they were convinced of the correctness of their doctrine, while they accused the Latins of having innovated by adding the Filioque and introducing other theological speculation. They therefore believed that examination of these issues in a council would end in the triumph of truth - that is to say, Orthodoxy, as it is the right faith - and in proving wrong the supporters of an erroneous doctrine ${ }^{13}$. On the Roman side, the council was in no way seen as a necessary tool for the completion of Union: the pope had the plenitudo potestatis allowing him to be accepted as supreme authority in the Church. The papacy therefore sought to obtain the return of the Greeks - reductio Graecorum - by an agreement between a pope and a Byzantine emperor, since the basileus was truly identified in Rome as the supreme authority over the Byzantine Church, to the detriment of the patriarch. In this context, the Union was to be prepared in advance by the diplomatic exchanges between Rome and Constantinople, and the council was of no use but the proclamation and ratification of the Union.

This discrepancy between the two interpretations of what a council should be became obvious in the 13th century. A first council sanctioned the Union of the Churches in 1215, the Fourth Council of the Lateran: pope Innocent III considered that the capture of Constantinople and

\footnotetext{
${ }^{13}$ See Nicol, "Byzantine requests”, pp. 69-95; Boojamra, “The Byzantine notion”, pp. 59-76.
} 
the founding of the Latin Empire effectively brought back the Byzantines into the fold of the Roman Church, so he proclaimed their return to the Roman obedience in canon 4 of the Council of the Lateran and granted them only the keeping of their own rites. This conciliary decision was never accepted by the Byzantine Church, whose patriarchs were then in exile at Nicaea alongside the emperors of the Laskaris dynasty. This kind of reconciliation through forced submission did not really form a precedent, since it was clear in retrospect that the Union of the Churches had not been achieved in $1215^{14}$. This was not true of the Union of Lyon in 1274, which appeared the very model of a genuine council of Union as understood by the papacy: the profession of faith of emperor Michael VIII Palaeologus read by the Byzantine ambassadors in Lyon bound both its author and the whole Byzantine Church to the recognition of the three points required by the pope, namely Roman primacy, right of appeal to Rome and commemoration of the pope in the diptychs of Constantinople. The controversial points of doctrine were not at all examined during the Council, contrary to what the Byzantines expected: the pope was satisfied with the text he himself had previously dictated to Michael VIII, and the Union was proclaimed. This was obviously not the sort of council demanded by the Byzantines ${ }^{15}$.

The violent reactions stirred up in Constantinople against the decisions of the Council of Lyon showed that it was impossible to impose Union on the Byzantine Church in this way. Throughout the period, especially during the preparations of the Council of Florence, the patriarch took care to specify the conditions that the Byzantines would be granted in the future $^{16}$. First, the council should imperatively be ecumenical, that is to say, all the Eastern patriarchs should be present or represented; moreover, the heads of the Slavic autocephalous Churches should be invited as well. In addition, the discussion should be public and focus on the contentious issues; the Byzantines should have the opportunity to present and defend their doctrine, and the only acceptable arguments should be based on the authority of the Scripture and Fathers' texts. The decisions made by the council should not be dictated by the will of the pope alone, but by general consensus, since the discussions about the controversial issues should bring to light the unquestionable dogmatic truth. These ideal conditions had been negotiated by Joseph II and John VIII Palaeologus and were initially observed at Ferrara and

\footnotetext{
${ }^{14}$ Andrea, "Innocent III and the Byzantine Rite", pp. 111-122.

${ }^{15}$ On the issues of the Union of Lyon, see Roberg, Das zweite Konzil von Lyon; see also Dossier grec de l'Union de Lyon, ed. Laurent. The most important Byzantine historical source about the events related to the Council of Lyon is George Pachymeres, History.

${ }^{16}$ See Sieben, "Griechische Konzilsidee”, pp. 184-215. See Joseph II, Letter to pope Martin V, ed. Laurent, pp. 31-57; Epistolae pontificiae, ed. Hofmann, No. 26, p. 20 and No. 47, p. 39, line 38-p. 40, line 39.
} 
Florence in 1438-1439; but as the situation was at a complete standstill at the end of the debates, especially about the Filioque, some expedients were found in order to come nevertheless to a solution and to conclude the Union, as the pope and the emperor both desired $^{17}$. Whereas the Byzantine Church, first of all the patriarchs, had high hopes that the conciliar way would guarantee the full respect of traditional dogma, they came to be disappointed every time.

The successive patriarchs appear to have been ultimately incapable of protecting the Byzantine Church from the imperial manoeuvring and unable to ensure the inviolability of Orthodoxy: despite their disagreement, they bent and bowed to the imperial will, even when it affected dogma. However, one may question the core of their position, beyond the official discourse they held: whereas the patriarchs seem to have been reluctant to conclude Union, and some of them more than the others, especially those coming from an often anti-Latin monastic environment such as Arsenios and Kallistos I, we cannot find any patriarch or former patriarch within the resistance movements to the Union. They did not actively commit themselves against it when it was achieved, neither after the Council of Lyon, nor after that in Florence. It is impossible to know how Joseph II would have acted if he had not died in Florence, but the attitude of Joseph I after 1274 showed his willingness to withdraw ${ }^{18}$. Another example is significant: after his return from Florence, John VIII had to have a new patriarch elected, since the see was vacant; he proposed that office to Mark of Ephesus, the metropolitan the most involved in the opposition to the Union during the Council itself, but Mark refused it: holding the position of patriarch would have not allowed him to carry on his fight ${ }^{19}$. It thus seems that, as an institution, the Byzantine Church represented by its patriarch could only comply with the imperial policy, while active resistance came from personalities who had broken with it, either members of the patriarchal administration who had resigned or monks or laymen, all of them having much more free speech than a patriarch.

One only text presents a leader of the Byzantine Church who openly proclaims his antiunionism and finally manages to rally the emperor to his opinion: this is a fictional dialogue between patriarch Michael of Anchialos and Manuel I Comnenus, which was

\footnotetext{
${ }^{17}$ On the issues of the Council of Florence, see Gill, The Council of Florence; Alberigo, Christian unity. The most important Byzantine historical source about the events related to the Council of Florence is Silvester Syropoulos, Memoirs, ed. Laurent.

${ }^{18}$ Pachymeres tells that Joseph I received antiunionists in his cell in his monastery, the reason why he was exiled by the emperor on the Black Sea; but Joseph I was not one of the leaders of the protest against the Union, and Pachymeres goes so far as to claim that Joseph would have accepted the Union had he not previously taken an oath to reject it: see George Pachymeres, History, 2, pp. 528-533.

${ }^{19}$ See Silvester Syropoulos, Memoirs, ed. Laurent, pp. 548-549.
} 
probably composed, as shown by J. Darrouzès, in the context of the Union of Lyon ${ }^{20}$. This dialogue reverses the roles of the emperor and the patriarch and assigns the latter the control on the debate. He starts with questioning the concessions provided to achieve Union, in particular the recognition of the right of appeal to the pope: how could indeed any authority be recognized to someone who is mistaken? From that point, the patriarch carries on with the blasphemy against the Holy Spirit which the Latins are guilty of, and the question of their condemnation as heretics. The content of the argumentation is quite conventional and similar to that of the Response by Joseph I, but the staging of the dialogue is original: the patriarch is set in a position of a master and provides the teachings of the Orthodox Church, while the emperor asks naive questions and raises easily refutable objections. In the 13th century, there were thus ecclesiastics - the author must have belonged to this environment - who dreamt of a reversal of power relations between emperor and patriarch and of a formal rejection of Union by the Byzantine Church.

The particular case of the unionist patriarchs

In actual fact, no patriarch opposed Union openly; on the contrary, some of them supported it and sought to enforce it. This is by no means the least of the paradoxes, whereas the Byzantine Church as a whole appears to have been rather hostile to Union, so that it should be interpreted as sign that different tendencies coexisted within the Church. There are three unionist patriarchs strictly speaking, that is to say, those who defended the Union concluded with Rome, over the entire period: John XI Bekkos, Metrophanes II and Gregory III Mammas. All three joined the Union as an afterthought, after having been initially opposed to it. All three were chosen by the emperor to hold the patriarchal office because of their overt unionist convictions. All three remained faithful to their commitment to the end, and together with some other theologians, embodied the Byzantine unionist movement: they declared themselves genuine Orthodox and felt that their faith was not endangered by the recognition of the Roman prerogatives and the validity of the Latin doctrine. Were they all three vile opportunists and did they become patriarchs out of ambition? Such an indictment was launched by their opponents, but their lasting influence, especially that of John Bekkos, invalidates this thesis: in his writings, $B^{2} k_{k o s}^{21}$, as well as Mammas ${ }^{22}$ to a lesser extent,

\footnotetext{
${ }^{20}$ See Dossier grec de l'Union de Lyon, ed. Laurent, pp. 346-375 et 45-52.

${ }^{21}$ About John Bekkos, see Riebe, Rom in Gemeinschaft ; Ragia, "Confessions of an ingenious man".

${ }^{22}$ About Gregory Mammas, see Harris, "The Patriarch".
} 
upheld the compatibility of Eastern and Western doctrines, while most Byzantine theologians considered Latin teachings heretic.

The issue at stake, and in fact the main doctrinal question raised repeatedly by the project of Union, was that of the double procession of the Holy Spirit, namely the Latin notion that the Holy Spirit proceeds from both the Father and the Son (Filioque). John XI Bekkos was the one who first gave legitimacy and authority to an Orthodox interpretation of the double procession of the Holy Spirit. He did not create alone his doctrine, but was inspired by the pneumatological treatises by Nicetas of Maroneia and Nicephorus Blemmydes. The issue lay in the participation or not of the Son in the intra-Trinitarian life of the Holy Spirit. The teachings of the Greek Fathers on this point recalled that the Father is the only source of divinity within the Trinity, while the Son is begotten by him and the Holy Spirit proceeds from him. But some Fathers added that the Holy Spirit proceeds from the Father "through the Son", and thus attributed a role to the Son in the eternal procession of the Holy Spirit. Bekkos deemed these texts of the Greek Fathers to be in agreement with those of the Latins in which the doctrine of the Filioque was grounded. Consensus Patrum, that is to say, the idea that all the Fathers of the Church express the same truth without contradicting each other, was a major argument for Bekkos and for the following supporters of Union, and Bekkos was the first who strove to gather within florilegia all the quotations of the Greek Fathers that justified his doctrinal position.

Convinced as he was of the possibility of a dogmatic agreement with the Latins on this basis, Bekkos supported the principle of Union, and started within Orthodoxy a lasting pro-Latin and unionist trend, which had its adherents even after the fall of Constantinople. But Bekkos had also to champion the Union of Lyon as it had been achieved with the papacy. The unionist patriarchs could not escape a deeply ambiguous situation: on the one hand, they took a theoretical stand supposedly compatible with the Orthodox faith which they were the highest representatives of, but on the other hand, in actual fact, they had to meet the often outrageous requirements of the popes. Whereas the Greek Symbol of the faith should not have been affected by the Union of Lyon, and no profession of faith including the Filioque was to be sent except those of the emperor and the patriarch, as Bekkos himself reminded in his letters in 1277, pope Nicholas III (1277-1280) eventually required the Byzantines to use the

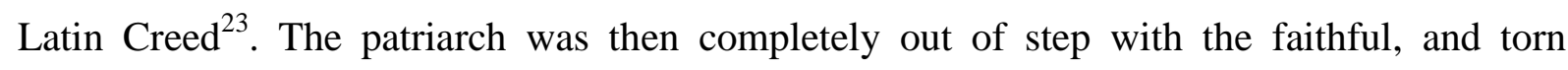
between the guarantees he had given concerning the limits of papal interventionism and the

\footnotetext{
${ }^{23}$ See Acta Romanorum pontificum, ed. Delorme, No. 35, pp. 70-77, especially p. 72.
} 
true expectations of Rome. The position of unionist patriarch proved to be untenable: the compromise that Bekkos, and after him Metrophanes II and Gregory III, sought to enforce had no chance of being accepted by the antiunionists, whereas it was also considered inadequate by the papacy.

The issue of the Union of the Churches was one of the most tricky that could be found for a patriarch of Constantinople. None of them would ever claim to be hostile to it, because they could not escape their moral duty to contribute to the restoration of Christian unity. As long as the Church was ideally regarded as one and indivisible, Union was by definition desirable. The Orthodox Church actually freed itself from this requirement only after the Council of Florence, when the division between Rome and Constantinople came to be considered insurmountable, and the existence of two distinct denominations was confirmed.

Bound throughout the medieval period to this abstract form of unionism, the patriarchs were at the same time very aware of the obstacles that the Byzantines might raise and the legitimate resistance they might offer to Union with Rome. Whatever their personal point of view, they were forced to take into consideration the arguments of the antiunionists, because the latter were obviously likely to derail the project of Union. In this respect, the very strong opposition to the Union of Lyon formed a precedent which all subsequent patriarchs had in mind. For these leaders of the Great Church, Union represented mostly a matter of discord that threatened the internal cohesion of their institution.

Under these circumstances, wasn't it a less costly solution for them to offload their responsibilities onto imperial power? Emperors entered into negotiations about Union with the papacy in order to gain political and military aid: it was then within their remit to meet the pope's expectations without in the same time raising the hostility of the clergy and the Byzantine faithful. The patriarchs could remind the sovereign of the importance of the dogmatic issues at stake in Union, and otherwise content themselves with playing a quite secondary role by getting involved as least as possible. I have emphasized in this analysis the weakness and submissiveness of all the patriarchs towards the imperial authority, the opponents to Union as well as the unionist patriarchs: this passiveness may be the result of the insoluble contradiction they faced when confronted with any project of Union.

Marie-Hélène Blanchet, CNRS (Paris), UMR 8167 Orient et Méditerranée 


\section{Bibliography}

Primary sources

Acta Romanorum pontificum ab Innocentio $V$ ad Benedictum XI, 1276-1304, ed. F.M. Delorme/A.T. Tăutu, Vatican City 1955

Arsene Autoreianos, Letter to the pope, ed. L. Pieralli, "Una lettera del patriarca Arsenios Autorianos a papa Alessandro IV sull'unione delle Chiese", Jahrbuch der Österreichischen Byzantinistik 48 (1998), 171-189

La corrispondenza diplomatica dell'imperatore bizantino con le potenze estere nel tredicesimo secolo (1204-1282) : studio storico-diplomatico ed edizione critica, ed. L. Pieralli, Vatican City 2006

Dossier grec de l'Union de Lyon 1273-1277, ed. V. Laurent/J. Darrouzès (Archives de l’Orient chrétien, 16), Paris 1976

Epistolae pontificiae ad Concilium Florentinum spectantes. 1, Epistolae pontificiae de rebus ante Concilium Florentinum gestis (1418-1438), ed. G. Hofmann (Concilium Florentinum. Documenta et scriptores 1, 1), Rome 1940

George Pachymeres, History, ed. V. Laurent/A. Failler, Relations historiques (Corpus Fontium Historiae Byzantinae, 24), Paris 1984-2000.

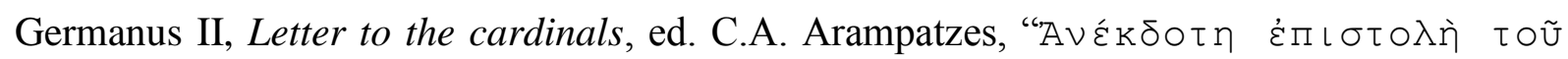

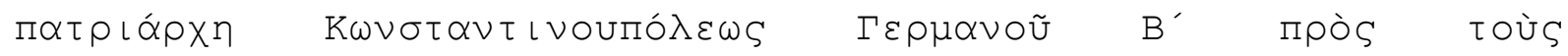

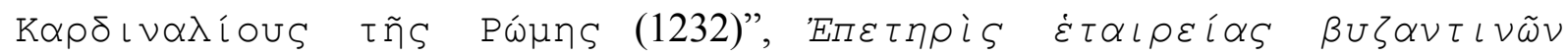

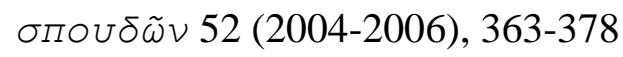

Joseph II, Letter to pope Martin V, ed. V. Laurent, "Les préliminaires du concile de Florence. Les neuf articles du pape Martin V et la réponse inédite du patriarche de Constantinople Joseph II (octobre 1422)”, Revue des études byzantines 20 (1962), 5-60 
Das Register des Patriarchats von Konstantinopel. 3, 1350-1363, ed. J. Koder [et al.], Vienna 2001

Silvester Syropoulos, Memoirs, ed. V. Laurent, Les «Mémoires » du Grand Ecclésiarque de l'Église de Constantinople, Sylvestre Syropoulos, sur le concile de Florence (1438-1439), (Concilium Florentinum. Documenta et scriptores, 9), Rome-Paris 1971

Secondary literature

Alberigo, G. (éd.), Christian unity. The Council of Ferrara-Florence 1438/39-1989, Louvain 1991

Andrea, A.J., "Innocent III and the Byzantine Rite, 1198-1216", in A. Laiou (ed.), Urbs Capta. The Fourth Crusade and its Consequences, Paris 2005, pp. 111-122

Boojamra, J., "The Byzantine notion of the 'ecumenical council' in the 14th century", Byzantinische Zeitschrift 80 (1987), 59-76

Dagron, G., Empereur et prêtre. Étude sur le «césaropapisme » byzantin, Paris 1996

Geanakoplos, D.J., "Church and State in the Byzantine Empire. A reconsideration of the problem of caesaropapism", Church History 34 (1965), 381-403 (republished in Idem, Byzantine East and Latin West, Oxford 1966, pp. 55-83)

Gill, J., The Council of Florence, Cambridge 1959

Harris, J., "The Patriarch of Constantinople and the Last days of Byzantium", dans C. Gastgeber (ed.), Das Patriarchat von Konstantinopel im Kontext und im Vergleich, Internationale Konferenz, Abteilung für Byzanzforschung/Institut für Mittelalterforschung der Österreichischen Akademie der Wissenschaften, Wien, 12.-15. September 2012, under press 
Kolbaba, T., "Byzantine perceptions of Latin religious 'Errors': themes and changes from 850 to 1350 ", in A. Laiou/R. P. Mottahedeh (eds.), The crusades from the perspective of Byzantium and the Muslim world, Washington 2001, pp. 117-143

Nicol, D.M., "Byzantine requests for an oecumenical council in the 14th century", Annuarium historiae conciliorum 1 (1969), 69-95 (republished in Idem, Byzantium: its ecclesiastical history and relations with the Western world, London 1972, $\mathrm{N}^{\circ} .8$ )

Ragia, E., "Confessions of an ingenious man: the confessions of faith of John XI Bekkos in their social, political and theological background”, in M.-H. Blanchet/F. Gabriel (ed.), L'Union à l'épreuve du formulaire. Professions de foi entre Églises d'Orient et d'Occident $\left(X I I I^{e}-X V I I I^{e} s.\right)$, under press

Riebe, A., Rom in Gemeinschaft mit Konstantinopel. Patriarch Johannes XI. Bekkos als Verteidiger der Kirchenunion von Lyon (1274), Wiesbaden 2005

Roberg, B., Das zweite Konzil von Lyon (1274), Paderborn 1990

Sieben, H. J., "Griechische Konzilsidee zur Zeit des Florentinums", Theologie und Philosophie 65 (1990), 184-215 